\title{
Wage differentials in domestic work: The impact of contractual arrangements
}

Fátima Suleman Conceição Figueiredo

Outubro de 2015 WP n. ${ }^{\circ} 2015 / 03$

DOCUMENTO DE TRABALHO WORKING PAPER 


\section{DINAMIR'CET}

ISCTE-WI.

\section{Wage differentials in domestic work: \\ The impact of contractual arrangements}

Fátima Suleman*

Conceição Figueiredo**

WP n. ${ }^{\circ} 2015 / 03$

DOI: 10.7749/dinamiacet-iul.wp.2015.03

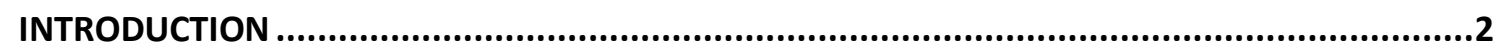

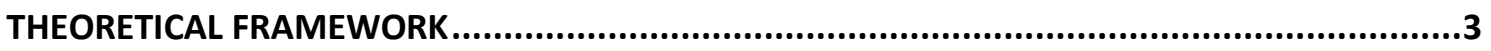

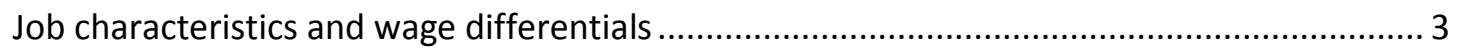

Regulation and contractual arrangements in the labor market of domestic workers .............. 5

The regulation on domestic work in Portugal................................................................... 8

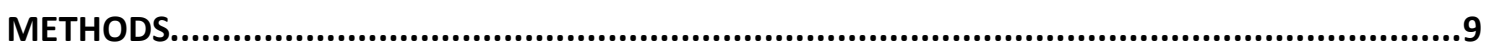

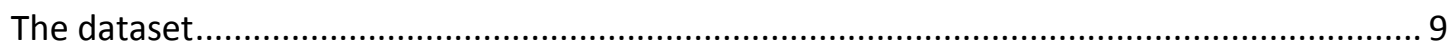

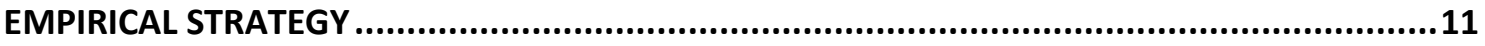

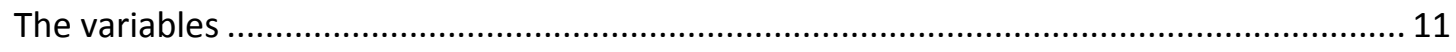

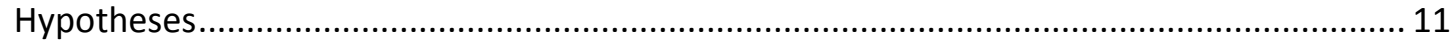

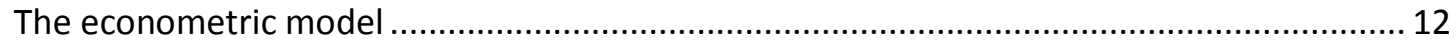

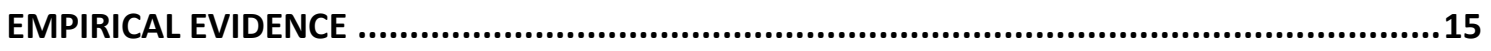

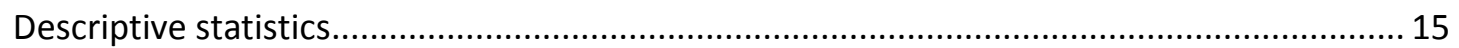

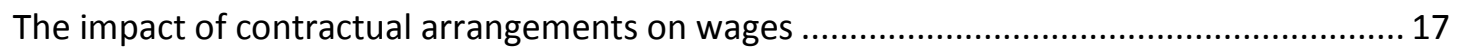

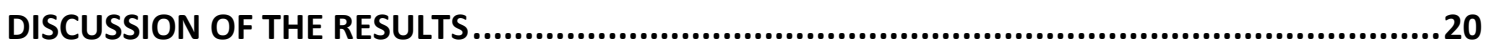

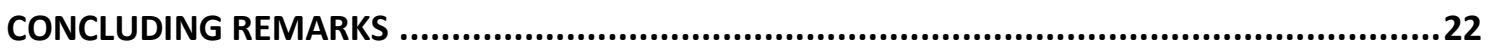

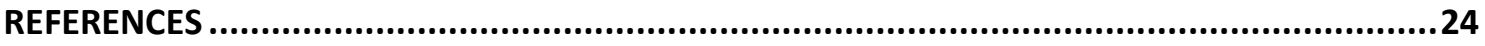

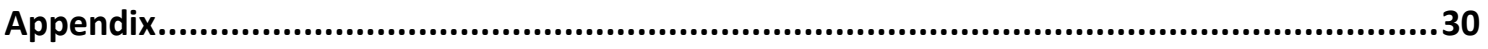

*DINAMIA'CET - IUL and ISCTE - University Institute of Lisbon (ISCTE-IUL) - Corresponding author: Fatima.Suleman@iscte.pt

**BRU-IUL and ISCTE - University Institute of Lisbon (ISCTE-IUL) - Corresponding author: Conceicao.Figueiredo@iscte.pt 


\section{Wage differentials in domestic work: The impact of contractual arrangements ${ }^{1}$}

\section{INTRODUCTION}

The regulation of employment relationships dates back to the process of industrialization where workers had dangerous and injurious working conditions. However, pervasive poor conditions, together with a wide range of contractual arrangements, demand additional efforts from national and international institutions. The Employment Relationship Recommendation (Recommendation 198) (ILO 2006) and the Decent Work Agenda, illustrate the International Labor Organization's (ILO 2002) efforts to guarantee protection of workers' rights in labor laws and other regulations, including collective agreements. These initiatives also attempt to bring more hidden types of employment relationships under the protection of the law. However, the assessment of the impact of such initiatives is still missing in the literature. Our article attempts to fill this gap and to offer empirical evidence on the role of regulations in the labor market of domestic workers.

In recent years, great attention has been paid to millions of domestic workers worldwide, mainly women and girls who perform tasks such as cooking, cleaning and caring in private households. Such workers are often poor and/or migrants that make them particularly vulnerable to abuse and exploitation (Anderson 1997; Duffy 2005; Nakano Glenn 2010). Most domestic work takes place on an informal basis, with low wages and poor working conditions. By performing their jobs within private houses, domestic workers become invisible to the rest of society and, until very recently, to researchers and policy makers. Statistics are scarce, but indicate that wages are the lowest among paid occupations in any labor market (ILO 2011; Shierholz 2013). However, the way in which the wages are set is still an important subject to be explored in the literature.

\footnotetext{
${ }^{1}$ Acknowledgments:

This research was possible thanks to data collected within Domestic Work and Domestic Workers: Interdisciplinary and Comparative Perspectives project granted by FCT - Foundation of Science and Technology, of Ministry of Education and Science PTDC/JUR/65622/2006. We have benefited from helpful comments on earlier versions of this study by ESPE Conference participants at the University of Minho, Braga, Portugal, June, 18-21, 2014 and ILP Conference at King's College, London, UK, 7-9 April, 2014. Luís Martins and Sérgio Lagoa are thankfully acknowledged for their invaluable comments and suggestions.
} 
Using original data from a sample of domestic workers in Portugal $(\mathrm{N}=684)$, we explore the determinants of wages and engage in the test of two apparently contrasting theoretical models, namely, the compensating wage differentials and the labor market segmentation in this particular sector. Our study focuses specifically on the impact of contractual arrangements on wages. We have learned from previous research that domestic workers may be engaged in multiple types of contractual arrangements, such as: work for a single or multiple employers, part time or full time employment, living-in or out or working in formal or informal jobs (Chen 2011; ILO 2010).

For a proper examination of the theoretical models, we estimate the impact of contractual arrangements that combine two relevant features of this specific labor market, namely, declaration (no declaration) and stability (flexibility) in domestic work. In our study, declaration is associated with the registration of the employment relationship to social security authorities, while stability is connected to the type of payment system. In Portugal, hourly and daily payments make flexibility a regular feature of contractual arrangements, while the monthly payment system may be used to develop stable relationships. For that reason, we focus on four types of arrangements in our study: declared and stable, undeclared and stable, declared and flexible and undeclared and flexible.

By doing so, we will be able to verify if good (bad) working conditions, proxied by the characteristics of contracts, correlate with higher (lower) wages. Additionally, we control for some socioeconomic characteristics that impact wages. However, domestic workers can select themselves into a contractual arrangement. Empirical analysis adopts the treatment effect model (Wooldrigde 2002) to deal with imprecise and inconsistent estimates arising from the OLS (Ordinary Least Squares) earnings model. To examine the impact of the four types of contractual arrangements on wages, we follow Deb and Trivedi (2006a and 2006b) and use a treatment-outcome model for multinomial choice of contractual arrangements.

\section{THEORETICAL FRAMEWORK}

\section{Job characteristics and wage differentials}

Two theoretical models draw attention to the non-pecuniary aspects of jobs in the labor market. The compensating wage differentials (CWD hereafter) theory explores the attempts to compensate workers for elements of unpleasantness or risk in jobs (Rosen 1986), while the labor market segmentation model supplies a picture of a dual labor market, where desirable job characteristics cluster with high wages, and undesirable characteristics are associated with low wages (Doeringer and Piore 1971). The predictions are therefore contradictory. 
The theory of CWD predicts higher wages to compensate workers for undesirable working conditions and, at same time, to attract them to those jobs. It thus serves as an incentive to workers to voluntarily perform dirty, dangerous, or unpleasant work. Likewise, for employers, CWD represents a financial penalty because of unfavorable working conditions offered to workers.

Despite the relevance of such an approach, empirical evidence is limited especially because the measures of working conditions that should imply compensation remain undefined (Duncan and Holmund 1983). While jobs with risks of death or injury give clear support to CDW arguments, other jobs are far less supportive (Brown 1980). Recent literature, tests the CWD hypothesis for flexible work arrangements: De la Rica and Felgueroso (1999) compare wage differentials between permanent and temporary workers, while Graaf-Zijl (2012) compare the differentials between on-call and fixed term jobs; Weeden (2005) explores the impact of flexible schedules and flexible work locations; Hamersma, Heinrich, and Mueser (2014) explore the wages and earnings of temporary help services, as well as estimate the pay gap between multiple job holders and temporary/non-temporary help service workers. The findings suggest that there is a compensation for flexible arrangements, namely, on-call workers have higher wages to compensate quantity flexibility (Graaf-Zijl 2012); flexible work entails higher wages than fixed-schedule and fixed-location counterparts (Weeden 2005); and temporary help service workers earn higher wages in comparison to other workers (Hamersma, Heinrich, and Mueser 2014). Fernandez and Nordman (2009) also confirm the presence of compensation for unfavorable working conditions but indicate that the amplitude and significance of the compensating differential is expected to differ along earnings distribution.

However, studies inspired in the CWD model tend to overlook informal jobs, which are a persistent characteristic of developing as well as developed countries. The definition of informal jobs has been the focus of international statistics (Hussmanns 2004) and it varies among studies (Bohn and Owens 2012). However, it is principally related to jobs that are partially or fully outside government regulation, taxation and observation (ILO 2002). Research adopts different proxies for informal jobs discriminating between job-category and benefitbased definitions (Pagés and Madrigal 2008). The former criterion includes, for example, selfemployment (Pradhan and Soest 1995; Marcoulier, Ruiz de Castilla, and Woodruff 1997; Maloney 1999); informal salaried workers in informal firms and contract workers (Maloney 1999). Benefit-based definition of informal employment includes, lack of pension coverage (Arias, 2007), jobs lacking social security coverage (Marcoulier, Ruiz de Castilla, and Woodruff 1997; Baskaya and Hulagu 2011) and jobs outside the benefits defined by country labor laws (Pratap and Quintin 2006).

\footnotetext{
DINÂMIA'CET - IUL, Centro de Estudos sobre a Mudança Socioeconómica e o Território ISCTE-IUL - Av. das Forças Armadas, 1649-026 Lisboa, PORTUGAL

Tel. 210464031 - Extensão 293100 E-mail: dinamia@iscte.pt http://dinamiacet.iscte-iul.pt/
} 
Pradhan and Soest (1995) suggest that male workers have higher wages in formal sectors, while women benefit from being employed in informal sectors. Marcoullier, Ruiz de Castilla, and Woodruff (1997) support substantial earnings differentials across countries: some countries show wage premium associated with informal jobs, while others have higher wages in formal jobs. Arias' (2007) estimates indicate that although there are significant differences among and within countries, on average, informal salaried workers are penalized in all countries. Furthermore, these differentials are not attributable to productive characteristics and are larger in low-pay jobs. The results are similar to ones achieved by Baskaya and Hulagu (2011) in their comparison between covered and uncovered workers.

This brief review summarizes major contrasting predictions in the literature of informality, namely, compensating wage differentials and labor market segmentation. Furthermore, literature on informality discusses the exclusion and voluntary perspectives, particularly in developing countries (Maloney and Arias 2007). The rationale underlying segmentation arguments is that workers actively seek to join high-level formal jobs but due to rationing in the formal labor market, they have to accept jobs in the informal markets. Against this involuntary view, some literature insists on workers' preference for informal jobs. Maloney (1999 and 2004) argues that much of the informal sector in developing countries is voluntary, i.e. workers have a preference for informal rather than formal jobs. Maloney insists that the premium for risk, independent lifestyle and social protections costs are some of the key explanations for that preference.

The reported literature reflects priorities in research agenda that tries to explore the specificities of informal work and deal with its social and economic implications. However, it lacks the particularities of wage differentials in a sector mostly characterized by informality and multiple contractual arrangements, such as domestic work (Chen 2011).

\section{Regulation and contractual arrangements in the labor market of domestic workers}

Domestic work is associated with reproductive work that enables productive workers to carry out their own jobs. Tasks include cleaning, cooking and caring tasks in private households. Furthermore, it is generally assumed that domestic work operates with rules different from other jobs in the economy (Chen 2011; Meagher 1997). First and foremost, the workplace is a private house. Domestic workers are therefore invisible to researchers and regulatory control; usually vulnerable to a various types of abuse; and engaged in unequal power relationships. Nevertheless, they tend to develop personal relationships with their employers, especially in the case of caring services (Chen 2011). This particularity makes them difficult to replace (Anderson 2007).

\footnotetext{
DINÂMIA'CET - IUL, Centro de Estudos sobre a Mudança Socioeconómica e o Território ISCTE-IUL - Av. das Forças Armadas, 1649-026 Lisboa, PORTUGAL

Tel. 210464031 - Extensão 293100 E-mail: dinamia@iscte.pt http://dinamiacet.iscte-iul.pt/
} 
In addition, there are trust issues (Ruijter, van der Lippe, and Raub 2003). These are related to the absence of employers when workers perform their domestic tasks, to uncertainty about the quality of the workers and the performed tasks, as well as the risk of opportunistic behavior. Employers entrust their home, family members and often the keys of the house to unknown people. In this regard Moras (2008) underlines that households almost always rely on references and recommendations from their network of friends, family and neighbors when making the decision to hire domestic workers from the informal labor market.

Secondly, it is well documented in the literature that domestic workers have lower wages, fewer benefits, and less legal or social protection compared to other workers (Shierholz 2013; Chen 2011; Tijdens and van Klaveren 2011). However, studies on how wages are set are still missing in the literature. To the authors' knowledge, one single study has been conducted by Shierholz $(2013)^{2}$ and compares the wages of different categories of domestic workers with similar workers in other occupations in the $\mathrm{US}^{3}$. Firstly, domestic workers are much more likely to be poor than other workers in other occupations. The estimates from OLS regression indicate: i) penalties for all segments of domestic work with direct-care ${ }^{4}$ workers having the most severe wage penalty; ii) differentials among demographic groups; iii) differences related to working time, with full time workers being the most penalized. Additionally, Shierholz reports scarce fringe benefits, especially employer-provided health insurance plans and pension plans. On the other hand, ILO's (2011) brief report proposes some hypotheses to explain wage differentials, namely undervaluation, pay discrimination, bargaining power, or minimum wage legislation and coverage.

Thirdly, particularity of domestic work is associated with workers' characteristics, which is explored through the intersection approach (Hondagneu-Sotelo 2007). Domestic work is intrinsically linked to gender, migration and ethnicity issues that increase the vulnerability of domestic workers (Nakano Glenn 2010; Moya 2007; Duffy 2005; Anderson 1997; Roberts 1997). It is largely fulfilled by immigrants, especially undocumented, ready to enter unqualified, dirty and dangerous jobs (Reyneri 2003). Therefore, the degree of persistence of informality in domestic work might also be due to the workers' decision, especially migrants, to remain

\footnotetext{
${ }^{2}$ Marcoulier, Ruiz de Castilla, and Woodruff (1997) excluded domestic work from their analysis because workers usually receive payment in kind and this information is unavailable in the dataset.

${ }^{3}$ Machin and Manning (2004) examine the structure of wages in a similar labor market, the one of care assistants. Their evidence rejected competitive labor market predictions, especially because of little wage dispersion within firms, and high dispersion between firms. However, the study focuses on firms rather than households that hire domestic workers to work at their houses.

${ }^{4}$ Shierholz (2013) discriminates three broad segments in what she calls "in home workers": maids and housekeeping cleaners, childcare workers that provide care in employers' homes - the nannies, and those who provide care in their own homes. There are also direct care aides, which include two subgroups those who are not agency-based and those who are agency-based.
} 
invisible if they are undocumented (Chen 2011). Furthermore, domestic workers are uncertain about the benefits or protections of formality within an activity performed in private households without monitoring for compliance with labor laws, Chen adds.

Non-negligible efforts have however been made by international and national bodies to promote decent work for domestic workers (see Blackett 2011 for a brief history). Blackett highlights that at the core of the law and practice, promoted by ILO initiatives, is to transform a status relationship, notably associated with domestic slavery and forced work, to a work relationship with labor rights and dignity. Several steps have been taken by international and national bodies to ensure that the transition from status relationships to work relationships has been effectively implemented. The major challenge in this regard is the adoption of the ILO Convention $189^{5}$, especially to include domestic work in the scope of labor legislation; to provide social protection and equitable pay, including minimum wage; and to ensure the right to create or join trade unions and bargain at collective levels (Blackett 2011; Caracciolo, Henry, and Rosenbusch 2011).

Particular efforts have been concentrated on expanding the social security coverage to domestic workers and social protection (Gomes and Puig 2013; Tokman 2010), simplifying the calculation and deduction schemes (Tomei, 2011), regulating overtime compensation (Mundlak and Shamir 2011) and regulating private employment agencies (Tsikata 2011). Despite relevant progress and examples of implementation of recommendations and national initiatives, the inequities between domestic workers and other workers still persist (Erdoğdu and Toksöz 2013; Grilo-Chope and Ramos 2006). The exclusion of domestic workers as workers is, in fact, originated from the law (Blackett 2011).

Therefore, the decision to engage domestic workers in an employment relationship is not independent from the acknowledgement of the economic and social relevance of domestic work, and more importantly the particularities of care work. While the topic is in itself a major social and economic issue, it deserves further attention at a time when countries worldwide are trying to promote decent work and dignity for domestic workers. Thus, the open questions are: How labor market and employer-based regulations impact the working conditions, especially the wages of domestic workers? Is there a wage gap between stable/flexible or formal/informal jobs?

\footnotetext{
${ }^{5}$ ILO 189 Convention, ratified in 2011, concerns decent work for domestic workers and entered into force in 2013: http://www.ilo.org/ilc/ILCSessions/100thSession/media-centre/press-releases/WCMS 157891/lang-en/index.htm.
}

DINÂMIA'CET - IUL, Centro de Estudos sobre a Mudança Socioeconómica e o Território ISCTE-IUL - Av. das Forças Armadas, 1649-026 Lisboa, PORTUGAL

Tel. 210464031 - Extensão 293100 E-mail: dinamia@iscte.pt http://dinamiacet.iscte-iul.pt/ 
Much of the research on domestic work has progressed towards socioeconomic characteristics, working conditions and regulations, but the impact of institutional initiatives is still unexplored in the literature.

\section{The regulation on domestic work in Portugal}

The Portuguese labor market provides an interesting case study due to the tradition of hiring live-in domestic workers, "criadas" (Brasão 2012), to it being a host country for female migrant domestic workers (Baptista 2011) and to extending much of the legal protection, which covers the general workforce, to domestic workers (GAMI 2012).

The legislation on domestic work in Portugal dates back to 1980 but much progress was made in the early 1990s. The Decree-law 235/92 stipulates the working conditions that employers must give workers, namely, the tasks to be performed, the pay and pay components including paid holidays and Christmas bonus, and other working conditions. According to this decree-law, employment contracts do not need to be in writing to be legally valid (Martins 2009). Formal contracts are obligatory only in the case of fixed term contracts and to obtain or renew visas for foreign workers. In all other relationships, domestic workers are recommended to formalize their contracts in order to enjoy more favorable social protection (GAMI 2012).

Like other paid workers in Portugal, domestic workers are entitled to the national minimum wage, which is set as a monthly-based pay at 485 Euros (in 2012) for live-in or fulltime workers. As regards the rates for social security contributions, domestic workers can choose between two plans, namely paying the rates on the basis of a pre-set wage or on the basis of the total earned wage (GAMI 2012). However, the social security rates levied on a pre-set wage are lower than those based on total earnings. In the first case the rates are $18.9 \%$ for employers and $9.40 \%$ for workers compared with $22.3 \%$ and $11 \%$ respectively when based on total earned wages; however, domestic workers are eligible for unemployment insurance schemes under the latter system. An additional requirement to be eligible for unemployment benefit is that domestic workers must have been in a full-time job with a monthly-based wage. Furthermore, social security authorities impose a minimum of 30 hours of work per month for the pre-set wage system.

The Portuguese government has ratified the ILO Convention 189 recently (Parliament Resolution 42/2015) and will expectedly implement those recommendations, while national bodies have taken active steps in developing materials and disseminating information on legal rights and legislations in domestic work (e.g. GAMI 2012). Nevertheless, the poor working conditions in domestic work in Portugal still persist. Illegal migration and undeclared work have largely contributed to the perpetuation of unfavorable conditions (Reyneri 2003; Pereira 2013). 


\section{METHODS}

\section{The dataset}

Our empirical analysis draws on an original cross-sectional dataset of domestic workers in Portugal collected in 2010 from an international project (see Guibentif 2011 for details). Given the characteristics of domestic workers and their workplace, snowball sampling was used to gain access to participants. The contact details of domestic workers were obtained from domestic work unions, immigration-related institutions, and personal acquaintances.

The data were gathered in face to face interviews and cover geographically dispersed domestic workers $(\mathrm{N}=684)$. The dataset includes detailed information on the following sociodemographic characteristics: gender, particular skills required in the hiring process, the relevant skills from the domestic worker's perspective, the demand for additional skills, assigned tasks, pay system, earnings, working time, working conditions, employment contracts, fiscal and social security contributions, employers' characteristics, and the domestic worker's family background.

Though some variables are self-descriptive, others deserve further explanation. For instance, information about contractual arrangements was collected by asking domestic workers, through yes/no questions, about the existence of a written employment contract, the payment of social security and income tax and the payment system including hourly, daily or monthly contracts. In addition, respondents reported if they worked for a single or several employers and if they were live-in or live-out workers.

The tasks performed were collected from a list of 19 items detailing the specific cleaning, cooking, child and elderly care tasks. We recoded domestic workers into three types of job: cleaners, children caregivers, and elderly care workers. It should be highlighted that the tasks of carers overlap with those of cleaners, but children care workers never take up elderly care tasks and vice-versa (Suleman and Suleman 2011).

The skills were assessed through self-perception of relevant skills. The questionnaire includes the following question: "If you were an employer, which skills would you look for in a domestic worker?" We assume that the workers would mention the skills they consider suitable to perform household tasks. This might proxy the skills required in the domestic work. The survey included further questions regarding the skills and abilities of domestic workers. Domestic workers were also asked whether their employers demanded specific requirements.

Trust issues including whether employers ask for references and how the domestic worker got the job were also addressed in the survey. Moreover, the sampled domestic workers stated whether they were entrusted with the key of the house and how work was monitored.

DINÂMIA'CET - IUL, Centro de Estudos sobre a Mudança Socioeconómica e o Território ISCTE-IUL - Av. das Forças Armadas, 1649-026 Lisboa, PORTUGAL

Tel. 210464031 - Extensão 293100 E-mail: dinamia@iscte.pt http://dinamiacet.iscte-iul.pt/ 
Monitoring activities were assessed through the presence (absence) of employer in the workplace during working hours.

Due to disparate records of earnings, we experienced difficulties in establishing data for hourly wages. Domestic workers reported their wages on an hourly, daily, weekly or monthly base. In order to achieve a standard that facilitates further analysis, we computed hourly wage using data on total working days per month and week, and the total working hours per day, reported by the domestic workers themselves. Of course, this was not necessary for readily available data on hourly wages.

The most difficult cases are those associated with live-in workers on call 24 hours a day. For these, we decided to consider at least 7 hours of rest per day and allocated 17 hours of work. On the other hand, as some live-in workers reported one day off per week, we excluded one day from the total days per week. However, the dataset does not include information on public holidays.

Where applicable, hourly wage accommodates the value related to Christmas and holiday bonuses. We weighted the hourly wage by 1.083 if the worker receives one bonus and 1.166 if there are two bonuses. In other words, the worker is paid 13 or 14 monthly wages a year. It should be stressed that some hourly-wage based domestic workers are entitled to bonuses and the weighting was applied in the same way in these cases. However, the dataset does not enable us to confirm whether the workers who reported receiving holiday allowances actually get paid holiday.

Finally, we use the net hourly wage. Our dataset includes declared or formal and undeclared or informal workers. The former bears the costs of social contributions ${ }^{6}$, while the informal workers earn the reported wages. For the sake of comparison, we deducted the social contributions costs from the wages of declared domestic workers, which vary among two plans (paying rates on the pre-set or total earned wage) and reduced their wages by $10 \%{ }^{7}$.

\footnotetext{
${ }^{6}$ The information on the contribution plan selected by the domestic workers is not available in the dataset. As the contributions vary between $9.40 \%$ and $11 \%$, we used an average of $10 \%$. However, the information on income taxes is unavailable in the dataset.

${ }^{7}$ Although the costs, the social security protection has short and long term benefits that cannot be captured by our model. For example, declaration allows accessing to unemployment insurance as well as to retirement benefits.
} 


\section{EMPIRICAL STRATEGY}

\section{The variables}

To test the impact of the proposed measures of contractual arrangements, this section describes the econometric model to estimate the wage differentials among four types of contractual arrangements that combine coverage by social security and stability: declared and stable; undeclared and stable; declared and flexible; and undeclared and flexible domestic workers. While the declared contract presupposes the declaration to social security authorities and the payment of respective contributions, the stability (flexibility) of the relationship is measured through the payment system, i.e. by monthly (hourly or daily) based system. From our day-today experience, households try to develop indefinite or continuing relationships by paying monthly-based wages instead of hourly or daily. This generally makes the relationship between households and domestic workers long term. Benefits associated with declaration reinforce the impact of labor market regulations in reducing inequalities, be it stable or flexible, and points to segmentation hypothesis, in that informal workers represent a disadvantaged group in the labor market. On the contrary, if the labor market enables undeclared workers to have positive wage differentials it suggests that informality is compensated by higher wages. The compensating wage differentials predictions are fully met by higher wages of undeclared and flexible arrangements.

In addition, our model includes a set of control variables for socioeconomic characteristics like age, origin which is mostly relevant in a market filled by migrants, marital status, job status to control for single or multiple employers, trust-related issues associated with the network to obtain a job and recommendation of the candidate, job requirements, namely the skills required to perform household tasks, occupational structure to explore the role of caring tasks and household characteristics related to the type of workplace (see Table A1 in Appendix for the description of variables).

\section{Hypotheses}

We propose to empirically test two contrasting theoretical hypotheses to explore the drivers of wages in the labor market of domestic workers:

Hypothesis 1: The compensating wage differentials assuming that domestic workers are compensated with higher wages for undeclared and flexible arrangements.

Hypothesis 2: Labor market segmentation arguing that undeclared and flexible workers suffer a wage penalization in the labor market.

DINÂMIA'CET - IUL, Centro de Estudos sobre a Mudança Socioeconómica e o Território ISCTE-IUL - Av. das Forças Armadas, 1649-026 Lisboa, PORTUGAL

Tel. 210464031 - Extensão 293100 E-mail: dinamia@iscte.pt http://dinamiacet.iscte-iul.pt/ 
Additionally, we test the predictions of human capital and impact of innate characteristics.

Hypothesis 3: Domestic workers are rewarded for their skills.

Hypothesis 4: The social origin of workers influences the wages of domestic workers.

\section{The econometric model}

Our first approach to explore the drivers of wages in domestic work is an OLS regression model, where the dependent variable is the hourly wage in logarithm form. However, the major problem in our estimation is the possibility of inconsistent estimators due to endogenous selection bias associated with the choice of contractual arrangement. Any worker in the economy can voluntarily choose informal jobs when entering the labor market simply because of his/her personal preference for or because he/she has to accept informal jobs due to the scarcity of formal ones (Maloney and Arias 2007). We assume that endogenous selection in domestic work arises because the knowledge of legal rights and benefits from regulations varies among domestic workers. As reported, domestic workers are doubtful about the benefits or protections of formality within an invisible activity performed in private households without monitoring for compliance with labor laws (Chen 2011). Therefore, those being aware of rights and benefits may have preference for formal arrangements, while others may choose informality. These traits have an impact on the choice and lead domestic workers to select contractual arrangements accordingly. Furthermore, national bodies seek to increase and broaden the access of domestic workers, and especially migrants, to their legal rights by increasing the knowledge of laws and labor rights in domestic work in Portugal (GAMI 2012).

To examine the impact of the four types of contractual arrangements on wages, we follow Deb and Trivedi (2006a and 2006b) and use a treatment-outcome model for multinomial choice of contractual arrangements. The treatment effects approach is suitable for dealing with endogenous selection as is the case of contractual arrangements in our wage determinants model (Maddala 1983; Imbens and Angrist 1994). The concept of treatment effects is inspired by the literature on the effects of medical treatment related to medicine tests before its introduction in the market. Binary variable represents the medical treatment, which takes the value 1 if the individual is treated with the medicine and 0 if he/she got a placebo. Therefore, literature suggests that treatment effects refer to an effect measured for a binary explanatory variable (Wooldridge 2002). Neglecting selection leads to correlation of the errors terms and consequently leads to an omitted variable bias.

DINÂMIA'CET - IUL, Centro de Estudos sobre a Mudança Socioeconómica e o Território ISCTE-IUL - Av. das Forças Armadas, 1649-026 Lisboa, PORTUGAL

Tel. 210464031 - Extensão 293100 E-mail: dinamia@iscte.pt http://dinamiacet.iscte-iul.pt/ 
However, we have multiple, instead of binary, arrangements, which call for the multinomial choice model (Deb and Trivedi 2006b). It is, in fact, an extension of the treatment model applied to multinomial choice. The model assumes joint distribution of endogenous treatment and wages using latent factor structure and applies maximum simulated likelihood approach for estimation. These econometric solutions are captured into mtreatreg Stata command and presuppose a model with two sets of equations: the selection and the outcome equations.

The determinants of contractual arrangements include the above-mentioned socioeconomic variables that influence wages and an additional instrument to illustrate domestic workers' knowledge of legal rights and benefits. The questionnaire asked domestic workers "if needed, would you be willing to use courts to appeal against any failures to comply with contractual obligations?" We assume that the affirmative answers to this question indicate the knowledge of rights and benefits associated with the type of contractual arrangement. As a consequence, informed workers will be more able to be engaged in legal and stable employment relationships, while ill-informed workers may select occasional and informal work.

It should be stressed that the matrix of covariates $\boldsymbol{z}_{i}$ does not necessarily require additional variables relative to $\boldsymbol{x}_{\boldsymbol{i}}$ to become identified. However, we have decided to include an exclusion restriction or instrument, the "knowledge of legal rights" in the treatment equation, as was suggested by Deb and Trivedi (2006a). Therefore, latent factors enter into the outcome and treatments equations in the same way as observed covariates and incorporate unobserved characteristics related to the knowledge of legal rights. On the other hand, since latent factors enter the likelihood function but are unknown, the maximization of the likelihood function is performed through simulation by drawing several random numbers from a standard normal distribution.

We give a formal representation of the model for the choice of contractual arrangement, where each individual $i$ chooses a type of contractual arrangement $j$ from a set of four choices $(j=0,1,2,3)$ where $j=0$ is the control group (undeclared and flexible). Let $E V_{i j}^{*}$ denote the utility associated with the hourly wage of individual $i$ contractual arrangement $j$ with and

$$
E V_{i j}^{*}=\mathbf{z}_{i}^{\prime} \alpha_{j}+\delta_{j} l_{i j}+\eta_{i j}
$$

where $\mathbf{z}_{i}$ denotes a set of exogenous covariates with parameters $\alpha_{j}, \eta_{i j}$ are i.i.d. error terms, and $l_{i j}$ are latent factors which incorporate unobserved characteristics common to the individual $i$ 's status choice and outcome (logarithm of hourly wage, $\omega_{i}$ ). The $l_{i j}$ are assumed to be 
independent of $\eta_{i j}$. As a normalization $E V_{i 0}^{*}=0$, so the expected utility of $j$-th status is the differential utility relative to undeclared and flexible arrangement.

Let $d_{j}$ be binary selection variables representing the observed contractual arrangement choice and $\mathbf{d}_{i}=\left(d_{i 1}, d_{i 2}, d_{i 3}\right)$. Also let $\mathbf{l}_{i}=\left(l_{i 1}, l_{i 2}, l_{i 3}\right)$. Then the mixed multinomial logit structure for the probability of contractual arrangement choice can be represented as

$$
P\left(\mathbf{d}_{i} \mid \mathbf{z}_{i}, \mathbf{l}_{i}\right)=\frac{\exp \left(\mathbf{z}_{i}^{\prime} \alpha_{j}+\delta_{j} l_{i j}\right)}{1+\sum_{k=1}^{J} \exp \left(\mathbf{z}_{i}^{\prime} \alpha_{k}+\delta_{k} l_{i k}\right)}
$$

The expected outcome equation for individual $i$ is formulated as

$$
E\left(y_{i}\right)=\mathbf{x}_{i}^{\prime} \beta+\sum_{j=1}^{3} \gamma_{j} d_{i j}+\sum_{j=1}^{3} \lambda_{j} l_{i j}
$$

where $\mathbf{x}_{i}$ is a set of exogenous variables and $\gamma_{j}$ denote the treatment effects relative to undeclared and flexible. The expected value of log hourly wage, $E\left(y_{i}\right)$, is a function of the latent factors $l_{i j}$ so that it is affected by unobserved characteristics which affect the selection into a contractual arrangement as well. The interpretation of the $\lambda_{j}$ factor-loading parameters is the following: when $\lambda_{j}$ is positive (negative), unobserved factors which increase the probability of selecting $j$-th contractual arrangement also increase (reduce) the hourly wage.

In order to estimate parameters of the model, latent factors are assumed to be i.i.d. Draws from the standard normal distribution and simulation-based method are used to maximize the log likelihood. Provided the number of draws is sufficiently large (we select 350 draws), maximization of the simulated log likelihood is equivalent to maximizing the $\log$ likelihood. Parameters of this model are identified when $\mathbf{z}_{i}=\mathbf{x}_{i}$, but Deb and Trivedi (2006b) recommend including some variables in $\mathbf{z}_{i}$ which are not included in $\mathbf{x}_{i}$. 


\section{EMPIRICAL EVIDENCE}

\section{Descriptive statistics}

Primarily, we used a principal components analysis (PCA) to reduce the 14 skills and abilities variables, measured by self-perception of required skills, to a smaller, more manageable number of components that explain a large proportion of the variance. The categories of skills grouped through PCA are: personal traits, specific skills, flexibility and general skills (see Table A2 for details in Appendix).

Table 1 provides summary statistics of variables, detailed in Table A1, used to estimate the determinants of wages in the labor market of domestic workers. It should be stressed that domestic work is almost exclusively a female job ( $99.6 \%$ of the sample) in Portugal.

Table 1

Descriptive statistics [mean, (SD)]

\begin{tabular}{|c|c|c|c|c|}
\hline & $\begin{array}{c}\text { Declared } \\
\text { and stable }\end{array}$ & $\begin{array}{l}\text { Undeclared } \\
\text { and stable }\end{array}$ & $\begin{array}{l}\text { Declared and } \\
\text { flexible }\end{array}$ & $\begin{array}{l}\text { Undeclared } \\
\text { and flexible }\end{array}$ \\
\hline Hourly wage (ln, [euro]) & $\begin{array}{c}1.309 \\
{[3.70]} \\
(0.465) \\
\end{array}$ & $\begin{array}{c}1.301 \\
{[3.67]} \\
(0.490) \\
\end{array}$ & $\begin{array}{c}1.681 \\
{[5.37]} \\
(0.344) \\
\end{array}$ & $\begin{array}{c}1.678 \\
{[5.35]} \\
(0.320) \\
\end{array}$ \\
\hline $\begin{array}{l}\text { Multiple employer } \\
(\text { Yes = 1) }\end{array}$ & $\begin{array}{c}0.460 \\
(0.499)\end{array}$ & $\begin{array}{c}0.455 \\
(0.502)\end{array}$ & $\begin{array}{c}0.760 \\
(0.429)\end{array}$ & $\begin{array}{c}0.636 \\
(0.483)\end{array}$ \\
\hline $\begin{array}{l}\text { Network to obtain job: } \\
\text { relatives (Yes }=1)\end{array}$ & $\begin{array}{c}0.184 \\
(0.388)\end{array}$ & $\begin{array}{c}0.209 \\
(0.410)\end{array}$ & $\begin{array}{c}0.211 \\
(0.409)\end{array}$ & $\begin{array}{c}0.135 \\
(0.343)\end{array}$ \\
\hline $\begin{array}{l}\text { Network to obtain job: } \\
\text { friends (Yes }=1)\end{array}$ & $\begin{array}{c}0.561 \\
(0.498)\end{array}$ & $\begin{array}{c}0.455 \\
(0.502)\end{array}$ & $\begin{array}{c}0.618 \\
(0.487)\end{array}$ & $\begin{array}{c}0.685 \\
(0.467)\end{array}$ \\
\hline $\begin{array}{l}\text { Network to obtain job: } \\
\text { others (Yes }=1)\end{array}$ & $\begin{array}{c}0.255 \\
(0.437) \\
\end{array}$ & $\begin{array}{l}0.209 \\
(0.41) \\
\end{array}$ & $\begin{array}{c}0.171 \\
(0.378) \\
\end{array}$ & $\begin{array}{c}0.180 \\
(0.386) \\
\end{array}$ \\
\hline $\begin{array}{l}\text { Employer required } \\
\text { particular skills }(Y e s=1)\end{array}$ & $\begin{array}{c}0.376 \\
(0.485) \\
\end{array}$ & $\begin{array}{c}0.246 \\
(0.434) \\
\end{array}$ & $\begin{array}{c}0.235 \\
(0.425) \\
\end{array}$ & $\begin{array}{c}0.153 \\
(0.362) \\
\end{array}$ \\
\hline $\begin{array}{l}\text { Personal traits } \\
\text { (PCA scores) }\end{array}$ & $\begin{array}{c}0.034 \\
(0.931)\end{array}$ & $\begin{array}{l}-0.018 \\
(1.030)\end{array}$ & $\begin{array}{l}-0.074 \\
(1.070)\end{array}$ & $\begin{array}{c}0.015 \\
(1.066)\end{array}$ \\
\hline $\begin{array}{l}\text { Specific skills } \\
\text { (PCA scores) }\end{array}$ & $\begin{array}{c}0.156 \\
(0.957)\end{array}$ & $\begin{array}{c}0.089 \\
(1.008)\end{array}$ & $\begin{array}{l}-0.175 \\
(0.988)\end{array}$ & $\begin{array}{l}-0.175 \\
(1.022)\end{array}$ \\
\hline $\begin{array}{l}\text { General skills } \\
\text { (PCA scores) }\end{array}$ & $\begin{array}{c}0.200 \\
(1.061) \\
\end{array}$ & $\begin{array}{l}-0.340 \\
(0.769) \\
\end{array}$ & $\begin{array}{l}-0.141 \\
(0.946)\end{array}$ & $\begin{array}{l}-0.122 \\
(0.934)\end{array}$ \\
\hline $\begin{array}{l}\text { Elderly caring tasks } \\
(\text { Yes = 1) }\end{array}$ & $\begin{array}{c}0.250 \\
(0.434) \\
\end{array}$ & $\begin{array}{c}0.130 \\
(0.339) \\
\end{array}$ & $\begin{array}{c}0.118 \\
(0.324) \\
\end{array}$ & $\begin{array}{c}0.09 \\
(0.288) \\
\end{array}$ \\
\hline $\begin{array}{l}\text { Children caring tasks } \\
(\text { Yes = 1) }\end{array}$ & $\begin{array}{c}0.242 \\
(0.429) \\
\end{array}$ & $\begin{array}{c}0.333 \\
(0.475) \\
\end{array}$ & $\begin{array}{c}0.164 \\
(0.372) \\
\end{array}$ & $\begin{array}{c}0.162 \\
(0.370) \\
\end{array}$ \\
\hline $\begin{array}{l}\text { Cleaning tasks } \\
(\text { Yes }=1)\end{array}$ & $\begin{array}{c}0.508 \\
(0.501) \\
\end{array}$ & $\begin{array}{c}0.536 \\
(0.502) \\
\end{array}$ & $\begin{array}{c}0.717 \\
(0.452) \\
\end{array}$ & $\begin{array}{c}0.748 \\
(0.436) \\
\end{array}$ \\
\hline Age (years) & $\begin{array}{c}43.518 \\
(10.772) \\
\end{array}$ & $\begin{array}{c}45.309 \\
(14.367) \\
\end{array}$ & $\begin{array}{c}41.47 \\
(11.562) \\
\end{array}$ & $\begin{array}{c}43.036 \\
(12.087) \\
\end{array}$ \\
\hline $\begin{array}{l}\text { Origin } \\
(\text { Migrant = 1) }\end{array}$ & $\begin{array}{c}0.357 \\
(0.480)\end{array}$ & $\begin{array}{l}0.275 \\
(0.45)\end{array}$ & $\begin{array}{c}0.329 \\
(0.471)\end{array}$ & $\begin{array}{c}0.315 \\
(0.467)\end{array}$ \\
\hline $\begin{array}{l}\text { Living in a house } \\
(\text { Yes = 1) }\end{array}$ & $\begin{array}{c}0.427 \\
(0.496) \\
\end{array}$ & $\begin{array}{c}0.382 \\
(0.490) \\
\end{array}$ & $\begin{array}{c}0.333 \\
(0.473) \\
\end{array}$ & $\begin{array}{c}0.288 \\
(0.455) \\
\end{array}$ \\
\hline $\mathrm{N}$ & 256 & 69 & 152 & 111 \\
\hline
\end{tabular}

DINÂMIA'CET - IUL, Centro de Estudos sobre a Mudança Socioeconómica e o Território ISCTE-IUL - Av. das Forças Armadas, 1649-026 Lisboa, PORTUGAL

Tel. 210464031 - Extensão 293100 E-mail: dinamia@iscte.pt http://dinamiacet.iscte-iul.pt/ 
At the outset, descriptive statistics suggest variations of wages among workers involved in different contractual arrangements. The figures displayed in Table 1 indicate wage differential among stable and flexible workers; and declared jobs, whether they are stable or flexible, impose slightly higher wages than undeclared ones. Furthermore, workers involved with multiple employers tend to earn higher wages than single-employer contracts.

A similar aspect of the type of contractual arrangements is evident in the access of additional payments. The evidence reported in Table 2 corroborates the benefits of being engaged in declared contracts.

\section{Table 2}

Pay package by contractual arrangements $(\%)$

\begin{tabular}{|l|c|c|c|c|}
\hline Pay components & $\begin{array}{c}\text { Declared and } \\
\text { Stable }\end{array}$ & $\begin{array}{c}\text { Undeclared } \\
\text { and Stable }\end{array}$ & $\begin{array}{c}\text { Declared and } \\
\text { Flexible }\end{array}$ & $\begin{array}{c}\text { Undeclared and } \\
\text { Flexible }\end{array}$ \\
\hline Christmas bonus & 80.5 & 53.6 & 51.0 & 28.8 \\
\hline Holiday allowances & 77.3 & 44.9 & 52.3 & 18.9 \\
\hline Health insurance & 30.2 & 7.4 & 13.4 & 3.6 \\
\hline Food allowance & 21.2 & 10.4 & 12.2 & 3.6 \\
\hline
\end{tabular}

As can be denoted, undeclared workers receive less favorable treatment in both situations. The pay package of declared and stable workers seems to be closer to the package of any other employees in the economy, while occasional workers draw non-negligible benefits from being declared. 


\section{The impact of contractual arrangements on wages}

The estimates from the OLS regression model displayed in Table $3^{8}$ indicate that stable contracts imply a non-negligible wage penalization to domestic workers. The difference is even greater for undeclared workers in stable contracts.

Table 3

Economic returns to contractual arrangements in domestic work: OLS estimates

\begin{tabular}{|c|c|}
\hline Model & Estimates \\
\hline \multicolumn{2}{|l|}{ Contractual arrangements ${ }^{\text {(a) }}$} \\
\hline Declared and stable $($ Yes $=1)$ & $\begin{array}{c}-0.267 * * * \\
(0.046)\end{array}$ \\
\hline Undeclared and stable $($ Yes $=1)$ & $\begin{array}{c}-0.350 * * * \\
(0.0 .61)\end{array}$ \\
\hline Declared and flexible $($ Yes $=1)$ & $\begin{array}{l}-0.002 \\
(0.043)\end{array}$ \\
\hline Multiple employer (Yes = 1) & $\begin{array}{c}0.135^{* * *} * \\
(0.036)\end{array}$ \\
\hline \multicolumn{2}{|l|}{ Network $^{(b)}$} \\
\hline Relatives $($ Yes $=1)$ & $\begin{array}{l}-0.009 \\
(0.045) \\
\end{array}$ \\
\hline Other network (Yes $=1)$ & $\begin{array}{l}-0.087^{*} \\
(0.046)\end{array}$ \\
\hline Demand for particular skills (Yes $=1$ ) & $\begin{array}{c}-0.114 * * * \\
(0.039)\end{array}$ \\
\hline \multicolumn{2}{|l|}{ Self-perception of relevant skills } \\
\hline Personal traits (PCA scores) & $\begin{array}{l}-0.0003 \\
(0.984)\end{array}$ \\
\hline Specific skills (PCA scores) & $\begin{array}{c}0.036 * * \\
(0.018) \\
\end{array}$ \\
\hline General skills (PCA scores) & $\begin{array}{c}-0.052 * * * \\
(0.017)\end{array}$ \\
\hline \multicolumn{2}{|l|}{ Occupational structure $^{(\mathrm{c})}$} \\
\hline Elderly caring tasks $($ Yes $=1)$ & $\begin{array}{c}0.021 \\
(0.051) \\
\end{array}$ \\
\hline Children caring tasks $($ Yes $=1)$ & $\begin{array}{l}-0.011 \\
(0.043)\end{array}$ \\
\hline Age (years) & $\begin{array}{l}0.0004 \\
(0.787)\end{array}$ \\
\hline Origin $($ Migrant $=1)$ & $\begin{array}{l}-0.050 \\
(0.191) \\
\end{array}$ \\
\hline Living in a house $($ Yes $=1)$ & $\begin{array}{c}-0.010 * * * \\
(0.038)\end{array}$ \\
\hline Constant & $\begin{array}{c}1.638 * * * \\
(0.082)\end{array}$ \\
\hline $\mathrm{N}$ & 557 \\
\hline $\mathrm{R}^{2}$ & 0.253 \\
\hline
\end{tabular}

Reference categories: ${ }^{(\mathrm{a})}$ Undeclared and flexible; ${ }^{(\mathrm{b})}$ Friends;

${ }^{(c)}$ Cleaning tasks. $(*)$ Statistically significant at the 0.10 level; $(* *)$ at the 0.05 level; $(* * *)$ at the 0.01 level

\footnotetext{
${ }^{8}$ We checked for correlation among variables and excluded some from the model. For example, multiple employer condition is negatively correlated with live-in status. A live-in domestic worker is hardly able to work for more than one employer. In all other variables the correlations are not statistically significant or negligible $(<|0.25|)$.
} 
Table 4 displays the estimates of treatment-outcome model for multinomial choice to control for endogenous selection bias. The results show that the estimates from OLS and treatment model vary considerably. The estimates with correction by treatment model reported in columns 5 show some relevant differences especially those associated with the impact of contractual arrangements. Furthermore, the lambda $(\lambda)$, which measures the impact of selection, is statistically significant for the three arrangements indicating that our prediction of endogenous selection is correct. The OLS estimates are therefore biased and we will continue our analysis on the basis of treatment approach estimates. Furthermore, our test of degree of substitutability among contractual arrangements revealed that IIA assumption has not been violated.

Table 4

Economic returns to contractual arrangements in domestic work: Endogenous multinomial treatment effect estimates

\begin{tabular}{|c|c|c|c|c|}
\hline & $\begin{array}{l}\text { Declared and } \\
\text { stable }\end{array}$ & $\begin{array}{c}\text { Undeclared and } \\
\text { stable }\end{array}$ & $\begin{array}{l}\text { Declared and } \\
\text { flexible }\end{array}$ & $\begin{array}{c}\text { ln (hourly } \\
\text { wage) }\end{array}$ \\
\hline Multiple employer $($ Yes $=1)$ & $\begin{array}{c}-0.617^{* * *} \\
(0.284)\end{array}$ & $\begin{array}{c}-0.736^{* *} \\
(0.373)\end{array}$ & $\begin{array}{c}0.756^{* *} \\
(0.317)\end{array}$ & $\begin{array}{c}0.183 * * * \\
(0.009)\end{array}$ \\
\hline \multicolumn{5}{|l|}{ Network $^{\mathrm{a}}$} \\
\hline Relatives (Yes=1) & $\begin{array}{c}0.560 \\
(0.391)\end{array}$ & $\begin{array}{c}0.363 \\
(0.495)\end{array}$ & $\begin{array}{c}0.580 \\
(0.400)\end{array}$ & $\begin{array}{c}-0.035^{* *} \\
(0.015)\end{array}$ \\
\hline Other network (Yes=1) & $\begin{array}{l}0.657^{*} \\
(0.372)\end{array}$ & $\begin{array}{c}0.398 \\
(0.496)\end{array}$ & $\begin{array}{c}0.184 \\
(0.392)\end{array}$ & $\begin{array}{c}-0.095 * * * \\
(0.014)\end{array}$ \\
\hline Demand for particular skills $($ Yes $=1)$ & $\begin{array}{l}0.860^{* * *} \\
(0.339)\end{array}$ & $\begin{array}{c}0.501 \\
(0.433)\end{array}$ & $\begin{array}{c}0.496 \\
(0.377)\end{array}$ & $\begin{array}{c}-0.082 * * * \\
(0.016)\end{array}$ \\
\hline \multicolumn{5}{|l|}{ Self-perception of relevant skills } \\
\hline Personal traits (PCA scores) & $\begin{array}{c}0.014 \\
(0.142)\end{array}$ & $\begin{array}{l}-0.063 \\
(0.188)\end{array}$ & $\begin{array}{l}-0.126 \\
(0.150)\end{array}$ & $\begin{array}{c}0.001 \\
(0.004)\end{array}$ \\
\hline Specific skills (PCA scores) & $\begin{array}{c}0.323^{* *} \\
(0.139)\end{array}$ & $\begin{array}{c}0.135 \\
(0.205)\end{array}$ & $\begin{array}{c}0.021 \\
(0.144)\end{array}$ & $\begin{array}{c}-0.062 * * * \\
(0.004)\end{array}$ \\
\hline General skills (PCA scores) & $\begin{array}{l}0.318^{* *} \\
(0.146) \\
\end{array}$ & $\begin{array}{l}-0.382 * \\
(0.200)\end{array}$ & $\begin{array}{l}-0.048 \\
(0.317)\end{array}$ & $\begin{array}{c}-0.043 * * * \\
(0.002) \\
\end{array}$ \\
\hline \multicolumn{5}{|l|}{ Occupational structure $^{(b)}$} \\
\hline Elderly caring tasks (Yes=1) & $\begin{array}{c}1.512 * * * \\
(0.408)\end{array}$ & $\begin{array}{c}0.819 \\
(0.588)\end{array}$ & $\begin{array}{c}0.198 \\
(0.461)\end{array}$ & $\begin{array}{c}0.095^{* * * *} \\
(0.008)\end{array}$ \\
\hline Children caring tasks $(\mathrm{Yes}=1)$ & $\begin{array}{c}0.972 * * * \\
(0.373)\end{array}$ & $\begin{array}{l}1.133^{* * *} \\
(0.446)\end{array}$ & $\begin{array}{c}0.227 \\
(0.391)\end{array}$ & $\begin{array}{c}-0.071 * * * \\
(0.016)\end{array}$ \\
\hline Age (years) & $\begin{array}{c}0.004 \\
(0.766)\end{array}$ & $\begin{array}{c}0.007 \\
(0.017)\end{array}$ & $\begin{array}{l}-0.009 \\
(0.013)\end{array}$ & $\begin{array}{c}-0.002 * * * \\
(0.0003)\end{array}$ \\
\hline Origin (Migrant $=1$ ) & $\begin{array}{c}0.345 \\
(0.303) \\
\end{array}$ & $\begin{array}{l}-0.052 \\
(0.420) \\
\end{array}$ & $\begin{array}{c}0.237 \\
(0.308) \\
\end{array}$ & $\begin{array}{c}-0.090 * * * \\
(0.010)\end{array}$ \\
\hline Living in a house (Yes=1) & $\begin{array}{l}0.625^{* *} \\
(0.295)\end{array}$ & $\begin{array}{c}0.589 \\
(0.389)\end{array}$ & $\begin{array}{c}0.191 \\
(0.317)\end{array}$ & $\begin{array}{c}-0.084 * * * \\
(0.008)\end{array}$ \\
\hline Knowledge of legal rights (Yes=1) & $\begin{array}{c}1.430 * * * \\
(0.282)\end{array}$ & $\begin{array}{c}0.183 \\
(0.374)\end{array}$ & $\begin{array}{c}1.268 * * * \\
(0.291)\end{array}$ & \\
\hline Constant & $\begin{array}{l}-1.183^{*} \\
(0.688) \\
\end{array}$ & $\begin{array}{c}-1.842^{* *} \\
(0.934) \\
\end{array}$ & $\begin{array}{l}-1.250^{*} \\
(0.687) \\
\end{array}$ & $\begin{array}{c}1.557 * * * \\
(0.018)\end{array}$ \\
\hline
\end{tabular}

DINÂMIA'CET - IUL, Centro de Estudos sobre a Mudança Socioeconómica e o Território ISCTE-IUL - Av. das Forças Armadas, 1649-026 Lisboa, PORTUGAL

Tel. 210464031 - Extensão 293100 E-mail: dinamia@iscte.pt http://dinamiacet.iscte-iul.pt/ 


\begin{tabular}{|c|c|}
\hline Contractual Arrangements $^{(\mathrm{c})}$ & \\
\hline Declared and stable $(\mathrm{Yes}=1)$ & $\begin{array}{c}-0.042 * * * \\
(0.013)\end{array}$ \\
\hline Undeclared and stable $(\mathrm{Yes}=1)$ & $\begin{array}{c}-0.245^{* * * *} \\
(0.017)\end{array}$ \\
\hline Declared and flexible $($ Yes $=1)$ & $\begin{array}{c}0.215^{* * *} \\
(0.011)\end{array}$ \\
\hline$\lambda$ (Declared and stable) & $\begin{array}{c}-0.273 * * * \\
(0.004)\end{array}$ \\
\hline$\lambda$ (Undeclared and stable) & $\begin{array}{c}0.071 * * * \\
(0.004)\end{array}$ \\
\hline$\lambda$ (Declared and flexible) & $\begin{array}{c}-0.300 * * * \\
0.003)\end{array}$ \\
\hline
\end{tabular}

Reference categories: ${ }^{(a)}$ friends; ${ }^{(b)}$ cleaning tasks; ${ }^{(c)}$ undeclared and flexible. $\left({ }^{*}\right)$ Statistically significant at the 0.10 level; $(* *)$ at the 0.05 level; $(* * *)$ at the 0.01 level.

The evidence from selection equation in Table 4 presents positive and significant signs of unobserved workers' characteristics proxied by the knowledge of legal rights and benefits in the declared arrangements. Domestic workers having that knowledge are $4.2\left(e^{1.430}\right)^{9}$ times more likely to be selected in declared and stable contracts, while they are $3.6\left(e^{1.268}\right)$ times more probable in declared but flexible arrangements. We conclude that self-selection exists and domestic workers choose an efficient arrangement.

Socioeconomic features are also relevant predictors of contractual arrangements. For example, the tasks to be performed and the skills required by households have a positive and significant impact on declared and stable contracts. The contracts involving working for multiple employers increase the probability of being engaged in flexible arrangements and at the same time decrease the likelihood of stable contracts in declared jobs. In addition, the estimates suggest that workplace characteristics have an impact on contractual arrangements. Employers living in houses are more likely to offer declared and stable jobs.

Our findings from the equation of interest, the outcome equation, are consistent with wage differentials among the range of contractual arrangements that cross declaration (no declaration) and stability (flexibility) in the labor market of domestic workers. Declared and stable workers have a wage penalization of almost $4.2 \%$ compared to counterfactual group of undeclared and flexible domestic workers, while the penalization of stable but undeclared workers is about $24.5 \%$. Furthermore, contingent workers, the ones being paid on an hourly or

\footnotetext{
${ }^{9}$ Powers and Xie (2000) encourage the use of odds ratio rather than marginal effects to interpret nonlinear models estimates.
}

DINÂMIA'CET - IUL, Centro de Estudos sobre a Mudança Socioeconómica e o Território ISCTE-IUL - Av. das Forças Armadas, 1649-026 Lisboa, PORTUGAL

Tel. 210464031 - Extensão 293100 E-mail: dinamia@iscte.pt http://dinamiacet.iscte-iul.pt/ 
daily basis, tend to have a high hourly wage, which is higher for declared workers. This finding is coherent with the multiple employer workers that have higher wages (18.3\%).

An interesting finding is associated with skills required to perform household tasks. General and specific skills are drivers of earnings in domestic work but negative and significant signs of the estimates are puzzling. The same holds for the negative sign associated with the requirement of particular skills. The trust-related estimate suggests that employers pay higher wages to domestic workers recommended by friends than to those hired from agencies or recommended by other networks. There are also wage differential between migrants and native workers. Being migrant imposes a wage penalization of almost $10 \%$. Finally, the employers living in houses tend to pay lower earnings than those living in apartments. They are also willing to pay higher wages for workers responsible for elderly care.

\section{DISCUSSION OF THE RESULTS}

The contractual arrangements in the labor market of domestic workers in Portugal are quite heterogeneous and parallel the typology proposed by Chen (2011). The results obtained from descriptive analysis indicate that domestic workers in Portugal work for one or a set of employers; are full-time for one employer or part-time for more than one household; are engaged in declared or undeclared relationships; earn on monthly basis, suggesting that they have, at least, a continuous relationship; or are contingent being paid on hourly or daily basis and live in the employer's house or are external workers. These properties of arrangements have non-negligible impacts on the wages earned by domestic workers.

The findings are consistent with wage differentials among arrangements and illustrate that regulations tend to reduce inequalities in the labor market. The wage penalization of stable workers meets the findings by Shierholz (2013) because full-time workers have lower wages in the labor market of domestic workers. However, it is lower for declared than for undeclared workers in the same condition, while the benefits of flexible contracts are higher for those that are declared compared to flexible and undeclared workers. As in Marcoullier, Ruiz de Castilla and Woodruff (1997) our findings suggest a wage premium for formal employment relationships, whereas workers assigned to informal jobs experience a wage penalization in the labor market (Arias 2007). Therefore, empirical evidence in this article adds the relevance of social security coverage that imposes some kind of minimum wage to hire domestic workers. In addition, the results corroborate the predictions of segmentation arguments because informal workers earn lower wages.

DINÂMIA'CET - IUL, Centro de Estudos sobre a Mudança Socioeconómica e o Território ISCTE-IUL - Av. das Forças Armadas, 1649-026 Lisboa, PORTUGAL

Tel. 210464031 - Extensão 293100 E-mail: dinamia@iscte.pt http://dinamiacet.iscte-iul.pt/ 
The benefits of declaration surpass wage differentials. Declared workers have additional monetary and non-monetary benefits. The data offered evidence on the larger proportion of workers earning Christmas and holiday bonuses within declared jobs than in informal employment relationships (Table 2). While Shierholz (2013) has highlighted the limited benefits for domestic workers, our study offers evidence on segmentation inside domestic work and illustrates that compensation packages vary among contractual arrangements. Additionally, the evidence reinforces the view that undeclared workers represent a secondary segment in the labor market and are more likely to lack benefits like health insurance or food allowances.

Empirical evidence is partially consistent with the presence of compensating wage differentials in the labor market of domestic workers (De la Rica and Felgueroso 1999). On average, workers benefit from contingent contracts. Compared to the group of monthly-based workers, contingent workers earn a higher hourly wage. The results indicate that those domestic workers working for multiple employers are compensated for their time when moving from household to household. The higher hourly wage of contingent workers does compensate for non-productive time.

At this stage, we can claim that no single theory predicts the determination of wages in the labor market of domestic workers. Furthermore, the predictions of human capital have been called into question. The negative signs of proxies of skills suggest that households demand for general and specific skills but are unwilling to reward them. The absence of monetary incentives associated with skills, evidences the undervaluation of domestic work (ILO 2011), which is usually perceived as an unskilled job. However, skills are important to access stable jobs, as can be drawn from selection equation. Ultimately, skills enable formality and stability in contracts; but are irrelevant to generating rents for domestic workers.

There are signals that stable relationships might be relevant for employers, especially when dealing with particularities of caring tasks. The findings from the selection equation suggest that care imposes more stability than cleaning, while the earnings equation offers evidence on higher wages for workers dealing with older people. Probably, elderly caregivers are compensated for the range of services given to help people maintain their wellbeing, dignity and autonomy, as well as being available at any time.

Finally, the estimates offered non-negligible wage differentials between migrant and native workers. In this light, we are able to corroborate claims of higher vulnerability of migrant domestic workers (Moya 2007; Duffy 2005) in Portugal. While the data illustrated that domestic work is almost exclusively a female job, the regression model offered evidence on lower wages of migrant women.

DINÂMIA'CET - IUL, Centro de Estudos sobre a Mudança Socioeconómica e o Território ISCTE-IUL - Av. das Forças Armadas, 1649-026 Lisboa, PORTUGAL

Tel. 210464031 - Extensão 293100 E-mail: dinamia@iscte.pt http://dinamiacet.iscte-iul.pt/ 


\section{CONCLUDING REMARKS}

Domestic workers are employed in private houses and their jobs are invisible, while their wages tend to be among the lowest in the labor market. They also have the propensity to be engaged in informal employment relationships constituting one of the most vulnerable categories of workers. However, working hand-in-hand with ILO, several countries, including Portugal, are reforming policies and legislation to dignify and give rights to domestic workers. Our study offers insights in this respect and shows evidence of the positive impact of regulations on the earnings of a sample of domestic workers in Portugal.

In fact, our estimates suggest that domestic workers who are legally hired benefit from declaration of their employment relationship to social security authorities. As afore-mentioned, social security contributions are paid on a pre-defined minimum hourly, daily or monthly wage, which contributes to increase the hourly wage. However, Portuguese social security law admits differentiation inside domestic work. While two plans contribution system (contributions on pre-set wage or total earnings) may encourage declaration, it also raises relevant differences in the access to benefits for domestic workers. This is particularly the case of social protection during spells of unemployment. As reported, only full-time and monthly paid workers are eligible for insurance, while contingent work, usually based on hourly wages, does not benefit from such protection. It has to be stressed that social security law reinforces segmentation inside domestic work.

There is a wage gap between stable/flexible and declared/undeclared workers. Domestic workers are compensated for their non-productive time when engaged in multiple and intermittent contracts. However, there is also a wage premium associated with formality. Our findings corroborate the hypothesis of compensating wage differential for contingent workers and support the hypothesis of labor market segmentation in that the informal workers represent a disadvantaged group. Therefore, the results boost the impact of regulations on earnings in the labor market of domestic workers after controlling for endogenous selection bias. Domestic workers in the sample select themselves into different contractual arrangements and use their knowledge of rights to demand for compliance with the law.

The study supplied a detailed analysis of the situation of the labor market of domestic workers in Portugal, which includes native and migrant workers. The findings will help encourage the dialogue between different labor market players and policy makers. Ultimately, the findings are particularly striking in Southern European labor markets which are mostly characterized by informality.

DINÂMIA'CET - IUL, Centro de Estudos sobre a Mudança Socioeconómica e o Território ISCTE-IUL - Av. das Forças Armadas, 1649-026 Lisboa, PORTUGAL

Tel. 210464031 - Extensão 293100 E-mail: dinamia@iscte.pt http://dinamiacet.iscte-iul.pt/ 
An important question arises however from our study. Declaration of the employment relationship imposes non-negligible costs for employers and workers Maloney (1999 and 2004). This brings us to a puzzle, which is at the core of the formalization discussion. The unanswered question is to what extent those costs are irrelevant in the context of wage cuts, especially for the middle class women who need the aid of domestic workers to participate in the labor market. Further research should assess households' perception about formality and the associated costs, while policy makers have to consider tax incentives to encourage declaration. It has to be stressed that dignity in domestic work can only be achieved when both players have the interest of being engaged in a true employment relationship.

Although our empirical evidence is interesting, all results must be regarded with caution. The sample is small, based on snowball sampling and therefore lacks randomness. However, it is extremely complicated to create a random and representative dataset due to the size and dispersed nature of the universe. 


\section{REFERENCES}

ANDERSON, B. (1997), "Servants and slaves: Europe's domestic workers.", Race and Class, XXXIX (1), pp. 37-49.

ANDERSON, B. (2007), "A very private business: exploring the demand for migrant domestic workers.", European Journal of Women's Studies, XIV (3), pp. 247-264.

ARIAS, O.S. (2007), "Informality, earnings, and welfare." Chap. 3 in G.E. Perry, W.F. Maloney, O.S. Arias, P. Fajnzylber, A.D. Mason, and J. Saavedra-Chanduvi (ed.), Informality: Exit and Exclusion, Washington D.C.: The International Bank for Reconstruction and Development/The World Bank.

BAPTISTA, P.G. (2011), Imigração e Trabalho Doméstico, Lisboa, ACIDI, IP.

BASKAYA, Y.S. and Hulagu, T. (2011), Informal-formal worker wage gap in Turkey: evidence from semi-parametric approach. Turkey: Central Bank of the Republic of Turkey, Working Paper, No.11/15.

BECKER, G. (1964), Human Capital, Chicago and London, The University of Chicago Press.

BLACKETT, A. (2011), "Introduction: Regulating decent work for domestic workers.", Canadian Journal of Women and the Law, XXIII (1), pp. 1-45.

BOHN, S., Owens, E.G. (2012), "Immigration and Informal Labor." Industrial Relations: A Journal of Economy and Society, LI (4), pp. 845-873 .

BRASÃO, I. (2012), O Tempo das Criadas: A condição servil em Portugal. Lisbon: Tinta-daChina.

BROWN, C. (1980), "Equalizing differences in the labor market." The Quarterly Journal of Economics, XCIV (1), pp. 113-134.

CARACCIOLO, B., Henry, G., Rosenbusch, S. (2011), "Domestic workers: from modern-day slavery to equal rights." Decent Work, Decent Life, SOLIDAR, Briefing 30 (May).

DINÂMIA'CET - IUL, Centro de Estudos sobre a Mudança Socioeconómica e o Território ISCTE-IUL - Av, das Forças Armadas, 1649-026 Lisboa, PORTUGAL

Tel. 210464031 - Extensão 293100 E-mail: dinamia@iscte.pt http://dinamiacet.iscte-iul.pt/ 
CHEN, M.A. (2011), "Recognizing domestic workers, regulating domestic work: conceptual, measurement, and regulatory challenges." Canadian Journal of Women \& the Law, XXIII (1), pp. 167-184.

DEB, P., Trivedi, P.K. (2006a), "Maximum simulated likelihood estimation of a negative binomial regression model with multinomial endogenous treatment." Stata Journal, VI(2), pp. 246-255.

DEB, P., Trivedi, P.K. (2006b), "Specification and simulated likelihood estimation of a nonnormal treatment-outcome model with selection: application to health care utilization." Econometrics Journal, IX (2), pp. 307-331.

DE LA RICA, S., Felgueroso, F. (1999), Wage differentials between permanent and temporal workers: further evidence. Unpublished paper, available at: www.ehu.es/SaradelaRica/docs/tempo-perma.pdf.

DOERINGER, P., Piore, M. (1971), Internal Labor Markets and Manpower Analysis. Lexington, MA: D. C. Heath.

DUFFY, M. (2005), "Reproducing labor inequalities: challenges for feminists conceptualizing care at the intersections of gender, race, and class.” Gender \& Society, XIX (1), pp. 66-82.

DUNCAN, G.J., Holmund, B. (1983), "Was Adam Smith right after all? Another test of the theory of compensating wage differentials". Journal of Labor Economics, I (4), pp. 366-379.

ERDOĞDU, S., Toksöz, G. (2013), The visible face of women's invisible labour: domestic workers in Turkey. Geneva: International Labour Office.

FERNANDEZ, R.M., Nordman, C.J. (2009), “Are there pecuniary compensations for working conditions?" Labour Economics, XVI (2), pp. 194-207.

GAMI (2012), Direitos e Deveres no Trabalho Doméstico, Lisbon: GAMI, http://www.solimigrante.org/wp-content/uploads/2012/04/Brochura-Direitos-e-

Deveres final2.pdf.

GLENN, E. N. (2010), Forced to Care: Coercion and Caregiving in America. Harvard University Press.

DINÂMIA'CET - IUL, Centro de Estudos sobre a Mudança Socioeconómica e o Território ISCTE-IUL - Av, das Forças Armadas, 1649-026 Lisboa, PORTUGAL

Tel. 210464031 - Extensão 293100 E-mail: dinamia@iscte.pt http://dinamiacet.iscte-iul.pt/ 
GRAAF-ZIJL, M. (2012), “Compensation of on-call and fixed-term employment: the role of uncertainty." The Manchester School, LXXX (1), pp. 6-27.

GUIBENTIF, P. (2011), La reconnaissance juridique du travail domestique. Paper presented at l'AFS Congress, Grenoble, July, 5-8

http://cadeiras.iscte-iul.pt/SDir/2011_PG_RecJurTravDom_CourtTablesCorr2.pdf.

GOMES, A., Puig, I.B. (2013), Domestic work after labour law: the case of Brazil and Spain. Paper presented at Labour Law Research Network Inaugural Conference, Barcelona: Pompeu Fabra University, June 13-15.

GRILLO-CHOPE, L., Ramos, C. (2006), Domestic workers working hard to sustain American families, compromising their social security. US: National Council of La Raza.

HAMERSMA, S., Heinrich, C., Mueser, P. (2014), “Temporary help work: earnings, wages and multiple job-holding." Industrial Relations: A Journal of Economy and Society, LIII(1), pp.72100.

HONDAGNEU-SOTELO, P. (2007), Doméstica: Immigrant Workers Cleaning and Caring in the Shadows of Affluence. Berkeley: University of California Press.

HUSSMANNS, R. (2004), Defining and measuring informal employment. Geneva: ILO.

ILO (2002), Decent work and the informal economy, Sixth item on the agenda. Geneva: ILO.

ILO (2006), The employment relationship, Fifth item on the agenda. Geneva: ILO.

ILO (2010), Decent Work for Domestic Workers. Geneva: ILO.

ILO (2011), Remuneration in domestic work. Domestic Work Policy Brief, No.1, Geneva: ILO.

IMBENS, G.W., Angrist, J.D. (1994), "Identification and Estimation of Local Average Treatment Effects." Econometrica, LXII (2) , pp. 467-475.

MACHIN, S., Manning, A. (2004), "A test of competitive labor market theory: the wage structure among care assistants in the south of England." Industrial and Labor Relations Review, LVII (3), pp. 371-385.

DINÂMIA'CET - IUL, Centro de Estudos sobre a Mudança Socioeconómica e o Território ISCTE-IUL - Av, das Forças Armadas, 1649-026 Lisboa, PORTUGAL

Tel. 210464031 - Extensão 293100 E-mail: dinamia@iscte.pt http://dinamiacet.iscte-iul.pt/ 
MADDALA, G.S. (1983), Limited-Dependent and Qualitative Variables in Econometrics. New York: Cambridge University Press.

MALONEY, W.F. (1999) "Does informality imply segmentation in urban labor markets? Evidence from sectoral transitions in Mexico.” The World Bank Economic Review, XIII (2), pp. $275-302$.

MALONEY, W.F. (2004), “Informality revisited.” World Development, XXXII (7), pp.11591178.

MALONEY, W.F., Arias, O.S. (2007), “The razón de ser of informal worker.” Chap. 2 in, Guillermo E. Perry, William F. Maloney, Omar S. Arias, Pablo Fajnzylber, Andrew D. Mason, and Jaime Saavedra-Chanduvi, Informality: Exit and Exclusion. Washington D.C.: The International Bank for Reconstruction and Development/The World Bank.

MARCOULLIER, D., Castilla, V.R., Woodruff, C. (1997), "Formal measures of the informal sector wage gap in Mexico, El Salvador, and Peru." Economic Development and Cultural Change, XLV (2), pp. 367-392.

MARTINS, A. (2009), Código do Trabalho e Legislação Complementar. Lisbon: Dislivro, $2^{\text {nd }}$ Edition.

MEAGHER, G. (1997), “Recreating 'domestic service': institutional cultures and the evolution of paid household work." Feminist Economics, III (2), pp. 1- 27.

MORAS, A. (2008), "The private home as a public workplace: employing paid domestic labor." Journal Workplace Rights, XIII(4), pp. 377-400.

MOYA, J.C. (2007), "Domestic service in global perspective: gender, migration and ethnic niches." Journal of Ethnic and Migration Studies, XXXIII (4), pp. 559-579.

MUNDLAK, G., Shamir, H. (2011), "Bringing together or drifting apart?: targeting care work as 'work like no other'." Canadian Journal of Women \& the Law, XXIII (1), pp. 289-308.

PEREIRA, S. (2013), "Replacement migration and changing preferences: immigrant workers in cleaning and domestic services in Portugal." Journal of Ethnic and Migration Studies, XXXIX (7), pp. 1141-1158.

DINÂMIA'CET - IUL, Centro de Estudos sobre a Mudança Socioeconómica e o Território ISCTE-IUL - Av, das Forças Armadas, 1649-026 Lisboa, PORTUGAL

Tel. 210464031 - Extensão 293100 E-mail: dinamia@iscte.pt http://dinamiacet.iscte-iul.pt/ 
PAGÉS, C., Madrigal, L. (2008), Is informality a good measure of job quality? Evidence from job satisfaction data. Inter-American Development Bank, Research Department, Working Paper, No. 654 .

POWERS, D.A., Xie, Y. (2000), Statistical Methods for Categorical Data Analysis, San Diego: Academic Press.

PRADHAN, M., Van Soest, A. (1995), "Formal and informal sector employment in urban areas of Bolivia." Labour Economics, II (4) , pp. 275-297.

PRATAP, S., Quintin, E. (2006), “Are labor markets segmented in developing countries? A semiparametric approach.” European Economic Review, L (7), pp. 1817-1841.

REYNERI, E. (2003), "Immigration and the underground economy in new receiving South European countries: manifold negative effects, manifold deep-rooted causes." International Review of Sociology: Revue Internationale de Sociologie, XIII (1), pp. 117-143.

ROBERTS, D.E. (1997), "Spiritual and menial housework." Yale Journal of Feminism and the Law, IX (1), pp. 5-80.

ROSEN, S. (1986), "The theory of equalizing differences." Chap 12 in Orley Ashenfelter and Richard Layard, Handbook of Labor Economics, Vol. 1, Elsevier.

RUIJTER, E., Van der Lippe, T., Raub, W. (2003), "Trust problems in household outsourcing." Rationality and Society, XV (4), pp. 473-507.

SHIERHOLZ, H. (2013), Low wages and scant benefits leave many in-home workers unable to make ends meet. Washington, DC: EPI Briefing Paper, No. 25.

SULEMAN, F., Suleman, A. (2011), The outsourcing of household tasks and labour contract in domestic work. Lisbon: DINAMIA’CET, Working Paper 2011/14.

TIJDENS, K., Van Klaveren, M. (2011), "Domestic workers. Their wages and work in 12 countries." WageIndicator Data Report, University of Amsterdam, Amsterdam Institute voor Arbeids Studies.

DINÂMIA'CET - IUL, Centro de Estudos sobre a Mudança Socioeconómica e o Território ISCTE-IUL - Av, das Forças Armadas, 1649-026 Lisboa, PORTUGAL 
TOKMAN, V. (2010), Domestic workers in Latin America: statistics for new policies, UK: WIEGO Working Paper, n. ${ }^{\circ} 17$.

TOMEI, M. (2011), "Decent work for domestic workers: reflection on recent approaches to tackle informality." Canadian Journal of Women \& the Law, XXIII (1), pp. 185-211.

TSIKATA, D. (2011), "Employment agencies and the regulation of domestic workers in Ghana: institutionalizing informality?" Canadian Journal of Women \& the Law, XXIII (1), pp. 213233.

WEEDEN, K.A. (2005), "Is there a flexiglass ceiling? Flexible work arrangements and wages in the United States." Social Science Research, XXXIV (2) , pp. 454-482.

Wooldridge, J.M. (2002), ECONOMETRIC ANALYSIS OF CROSS SECTION AND PANEL DATA. CAMBRIDGE, MA: MIT Press. 


\section{Appendix}

\section{Table A1}

Description of the variables in the model

\begin{tabular}{|c|c|}
\hline Variable & Definition of the variable \\
\hline \multicolumn{2}{|l|}{ Dependent variable } \\
\hline Hourly wage & $\begin{array}{l}\text { Natural logarithm of hourly net wage: } \\
\text { reported wage minus } 10 \% \text { for declared workers } \\
\text { (Euro) }\end{array}$ \\
\hline \multicolumn{2}{|l|}{ Explanatory variables } \\
\hline \multicolumn{2}{|l|}{ Contractual arrangements } \\
\hline Declared and stable & 1 if yes; 0 otherwise \\
\hline Undeclared and stable & 1 if yes; 0 otherwise \\
\hline Declared and flexible & 1 if yes; 0 otherwise \\
\hline Undeclared and flexible & 1 if yes; 0 otherwise \\
\hline \multicolumn{2}{|l|}{ Job status } \\
\hline Multiple employer & 1 if yes; 0 otherwise \\
\hline $\begin{array}{l}\text { Trust issues } \\
\text { Network to obtain job: } \\
\text { relatives }\end{array}$ & \multirow{3}{*}{$\begin{array}{l}1 \text { if yes; } 0 \text { otherwise } \\
1 \text { if yes; } 0 \text { otherwise } \\
1 \text { if yes; } 0 \text { otherwise }\end{array}$} \\
\hline Network to obtain job: friends & \\
\hline Network to obtain job: others & \\
\hline \multicolumn{2}{|l|}{ Specific skill requirements } \\
\hline $\begin{array}{l}\text { Employer required particular } \\
\text { skills }\end{array}$ & 1 if yes; 0 otherwise \\
\hline \multicolumn{2}{|l|}{ Self-perception of relevant skills } \\
\hline Personal traits & PCA analysis scores \\
\hline Specific skills & PCA analysis scores \\
\hline General skills & PCA analysis scores \\
\hline \multicolumn{2}{|l|}{ Occupational structure } \\
\hline Elderly caring tasks & 1 if yes; 0 otherwise \\
\hline Children caring tasks & 1 if yes; 0 otherwise \\
\hline Cleaning tasks & 1 if yes; 0 otherwise \\
\hline \multicolumn{2}{|l|}{ Workers' characteristics } \\
\hline Age & Age reported (years) \\
\hline $\mathrm{Age}^{2}$ & Squared age (years) \\
\hline Origin & 1 if Migrants; 0 Native \\
\hline Marital status: single & 1 if yes; 0 otherwise \\
\hline $\begin{array}{l}\text { Marital status: widow or } \\
\text { divorced }\end{array}$ & 1 if yes; 0 otherwise \\
\hline Marital status: married & 1 if yes; 0 otherwise \\
\hline Employers' characteristics & 1 if living in a house; 0 apartment \\
\hline
\end{tabular}


Table A2 displays the estimated factors, and indicates that four factors with eigenvalue greater than one explain $53.49 \%$ of the variance of skills. The value of the KMO test (0.811) reveals a good adequacy of the sample.

Table A2

The self-perception of relevant skills: principal component analysis

\begin{tabular}{ll}
\hline $\begin{array}{l}\text { PCA factors: Explained variance } \\
\text { (Cronbach Alpha) }\end{array}$ & Skills and abilities \\
\hline Factor 1: Personal traits & Personal service (dealing with people) \\
26.6\% (0.695) & Problem solving \\
& Discretion \\
& Humility \\
& Work satisfaction \\
\hline Factor 2: Specific skills & Care experience \\
$9.6 \%(0.686)$ & Active listening \\
& Counseling \\
\hline Factor 3: Flexibility & Ability to adapt \\
$9.3 \%$ (0.381) & Work autonomy \\
& Rapidity \\
\hline Factor 4: General skills & General experience \\
$7.95 \%$ (0.526) & Availability \\
& Training \\
\hline
\end{tabular}

On further analysis of the main components, we find that the abilities labeled as "personal traits" explain $26.6 \%$ of the variability of data including traits like humility, discretion, and work satisfaction. Two other components ( 2 and 4 ) show the relevance of general and specific experience. Finally, the third component brings together the skills related to autonomy in work and ability to adapt. Table 6 also presents the Cronbach alpha in parentheses after the proportion of explained variance. The estimates reported for skill and ability subsets range between 0.381 and 0.695. Given the very low internal consistency of the factor labeled as "flexibility", we decided to exclude it in further analyses. 